\title{
Cinética da Degradação Ruminal do Capim Tanzânia Irrigado sob Três Níveis de Resíduo Pós-Pastejo ${ }^{1}$
}

\author{
Marco Antonio Alvares Balsalobre ${ }^{2}$, Moacyr Corsi ${ }^{3}$, Patrícia Menezes Santos ${ }^{4}$, \\ Marco Antonio Penati ${ }^{5}$, Clarice Garcia Borges Demetrio ${ }^{6}$
}

\begin{abstract}
RESUMO - O uso do programa de Cornell indica a necessidade de estudos sobre a degradação dos diferentes componentes da matéria seca (MS). O objetivo deste trabalho foi avaliar a cinética ruminal da MS e das frações fibra em detergente neutro (FDN), proteína bruta (PB) e proteína insolúvel em detergente neutro (PIDN) de amostras de capim-Tanzânia (Panicum maximum Jacq.) obtidas por simulação de pastejo, coletadas em três épocas do ano (verão, outono e primavera), em pastagens irrigadas submetidas a três níveis de resíduo pós-pastejo (baixo, médio e alto). Para cada período de incubação, foram usados três animais fistulados no rúmen. Os tempos de incubação foram: 0, 3, 6, 9, 12, 24, 30, 48, 60, 72, 96 horas. No resíduo do material incubado, foram determinados os teores de FDN, PB e PIDN, utilizando-se NIRS. O nível de resíduo baixo foi o tratamento que apresentou maior redução de degradabilidade potencial entre o verão $(81,41 \%)$ e a primavera $(74,96 \%)$. A fração prontamente solúvel da proteína pode ser maior que $40 \%$ da proteína degradável no rúmen (PDR), que variou entre 76,36 e 62,05\% da PB. A fração indegradável da FDN (C) é maior que a estimada pelo CNCPS a partir dos teores de lignina/FDN multiplicados por 2,4. Os resultados deste trabalho indicam que o fator de multiplicação deve estar entre 2,91 e 3,35. A fração C do PIDN (12,11 a 17,08\%) é maior que a calculada em laboratório como nitrogênio aderido à fibra em detergente ácido (N-FDA) (6,48 a 10,7\%). Quanto maior o teor de PB e de PIDN, pior a degradabilidade da PB.
\end{abstract}

Palavras-chave: CNCPS, degradabilidade, FDN, irrigação, NIRS, PDR

\section{Ruminal Kinectics of Irrigated Tanzaniagrass under Three Post Grazed Stubbles Intensities}

ABSTRACT - The objective of this work was to study DM, NDF, CP and IPND ruminal kinectics of irrigated Tanzaniagrass (Panicum maximum Jacq.). Simulated grazed samples were collected on three periods of the year (spring, summer and fall), under three post grazed stubbles intensities (low, medium and high). Three rumen cannulated animals were assigned to a $3 \times 3$ Latin square design to determine the in situ degradability until 96 hours of incubation. NDF, CP and IPND were determined by NIRS in the residue remaining in the bags. Forage quality was the highest in the summer. The low post grazed stubble treatment showed the highest increase in degradability of all fractions from spring $(74.96 \%)$ to summer $(81.41 \%)$. The soluble protein fraction showed values up to $40 \%$ of the RDP, which ranged from 62 to $76 \% \mathrm{CP}$. NDF C fraction was underestimated by CNCPS. Data of this research suggest that the \%lignin/\%NDF should be multiplied by a factor from 2.91 to 3.35. CNCPS overestimated the IPND C fraction (12.11 to $17.08 \%$ ), as compared to the wet lab analysis value, as regarded to be the N-ADF fraction (6.48 to $10.7 \%$ ). CP and IPND degradability decreased, as the CP and IPND contents increased.

Key Words: CNCPS, degradability, DIP, irrigation, NDF, NIRS

\section{Introdução}

Na busca da sincronização entre a degradação ruminal de carboidratos e proteína, faz-se necessário determinar as taxas de degradação da matéria seca e das diferentes frações que compõem os carboidratos e as proteínas. Com o surgimento e evolução do programa de Cornell (CNCPS) (Sniffen et al., 1992; Russell et al., 1992; Fox et al., 1992), uma nova forma de se estimar o desempenho de bovinos foi adotada. Até então, os programas de predição de desempenho eram estáticos, não levando em consideração os vários componentes do alimento com suas diferentes taxas de degradação ruminal e suas interações. O CNCPS é um sistema dinâmico, adotando taxas de passagem e taxas de degradação diferenciadas para cada fração da proteína e dos carboidratos.

\footnotetext{
${ }_{1}^{1}$ Parte da tese de doutorado do primeiro autor. Trabalho financiado pela FAPESP.

2 Aluno de doutorado em Ciência Animal e Pastagens, ESALQ/USP, Piracicaba. E.mail: marcobalsalobre@bellamn.com.br

3 Professor Titular do Depto de Produção Animal, ESALQ/USP, Piracicaba. E.mail: moa@carpa.ciagri.usp.br

4 Pesquisadora da Embrapa Pecuária Sudeste, São Carlos. E.mail: patricia@cppse.embrapa.br

5 Aluno de doutorado em Ciência Animal e Pastagens, ESALQ/USP, Piracicaba. E.mail: mapenati@carpa.ciagri.usp.br

${ }^{6}$ Professora Titular do Depto de Ciências Exatas, ESALQ/USP, Piracicaba. E.mail: clarice@carpa.ciagri.usp.br
} 
Além do espessamento da parede secundária, a degradabilidade da parede celular é influenciada tanto pelo teor como pelas características físicas dos polissacarídeos da parede, como o grau de cristalinidade e polimerização (Fritz et al., 1990).

A hemicelulose é a fração mais afetada pela lignificação. Apesar dessa fração apresentar maior potencial de degradação que outros componentes da parede celular, essa não é maximizada, pois se concentra, principalmente, na parede primária. Como a degradação da célula inicia-se pelo seu interior seguindo para a parede secundária, quando o microrganismo atinge a parede primária, que é a porção externa da célula, a partícula já está deixando o rúmen. Desse modo, plantas forrageiras de maior idade fisiológica, ou florescidas, apresentam maior redução na degradabilidade da hemicelulose que da celulose (Messman et al., 1991).

Assim, o aumento no teor de lignina afeta diretamente a fração degradável da FDN (Caballero et al., 2001). Como o teor de lignina aumenta em proporção maior que o teor de FDN com o avanço da idade da planta, a degradação da matéria seca tem correlação maior com a degradabilidade da FDN que com o teor dessa fração (Deschamps, 1999).

Vieira et al. (2000b) avaliaram as taxas de degradação das frações dos carboidrato de amostras de extrusa em pastagens nativas coletadas em duas épocas do ano: águas e seca. A fração dos carboidratos fibrosos disponível dessas amostras apresentou taxas de degradação de $9,00 \% /$ h no período das águas e de $6,20 \% / \mathrm{h}$ no período de seca. Enquanto, a degradação efetiva (DE) dessas amostras foi de 73,50 e 68,50\% para águas e seca, respectivamente.

Ribeiro et al. (2001) avaliaram a cinética ruminal em amostras de feno de Tifton- 85 colhido em diferentes idades de rebrota (28, 35, 42 e 56 dias). A taxa de degradação dos carboidratos fibrosos disponíveis variou de 4,00 a $4,66 \% / \mathrm{h}$, sendo os menores valores para plantas de maior idade fisiológica.

O CNCPS, em sua última versão, apresenta um banco de dados para plantas tropicais. Para essas plantas, a taxa de degradação da porção da fibra disponível, em média, é de 4,86\%/h. Plantas de capim Guine (Panicum maximum) são apresentadas com taxas de degradação para a FDN na ordem de 7\%/h. No entanto, o banco de dados de Cornell apresenta grande variação para as taxas de degradação da fibra de plantas tropicais (3 a $8,10 \% / \mathrm{h})$.
Malafaia et al. (1997) caracterizaram as frações nitrogenadas e avaliaram a cinética ruminal dessas frações em algumas gramíneas tropicais. Em plantas de Tifton-85, capim-elefante, Brachiaria brizantha e Brachiaria decumbens, encontraram para a fração B3 (proteína potencialmente degradável associada à parede celular) taxas de degradação de 0,$15 ; 0,06$; 0,$25 ; 0,95 \% / \mathrm{h}$. Essas taxas de degradação das frações protéicas foram determinadas através da utilização de proteases oriundas da microbiota ruminal. Para plantas de Tifton-85 e capim-elefante, o NRC (1996) sugere $0,09 \% /$ h como taxa de degradação da fração B3.

Ribeiro et al. (2001) avaliaram a taxa de degradação da fração B3 da proteína de amostras de feno de Tifton- 85 colhido em diferentes idades de rebrota (28, 35,42 e 56 dias). A taxa de degradação variou de 0,77 a $1,20 \% / \mathrm{h}$, sendo que houve tendência de serem menores em idades avançadas da planta.

Vieira et al. (2000a) trabalharam com o fracionamento de amostras da extrusa de animais em pastagens naturais da Zona da Mata, MG. Essas amostras foram coletadas quatro vezes em duas épocas do ano, chuvas e seca. As determinações das taxas de degradação e da degradação potencial da fração B3 da proteína foram realizadas in vitro com proteases originadas do Streptomyces griseus. A taxa de degradação variou entre 3,2 e $8,0 \% / \mathrm{h}$. Os maiores valores encontrados foram para início da estação das chuvas, assim como para a degradação potencial dessa fração protéica $(59,50$ a 79,60\%).

As taxas de degradação da proteína encontradas por Vieira et al. (2000a) apontam para valores bem maiores que os indicados por Malafaia et al. (1997) e Ribeiro et al. (2001). Vieira et al. (2000a) justificam essas diferenças de duas formas: devido ao tratamento matemático aplicado aos diferentes intervalos de linearidade para degradação de cada fração (Vieira et al., 1997), e também por serem suas análises originadas de amostras de extrusa, o que pressupõe melhor qualidade quando comparadas com amostras simulando o pastejo. Provavelmente, o principal fator que contribuiu para a maior taxa de degradação verificado por Vieira et al. (2000) foi o tipo de enzima utilizado, principalmente, quando comparados aos dados obtidos por Malafaia et al. (1997). Sabe-se que enzimas oriundas de Streptomyces griseus resultam em taxas de degradação superior àqueles obtidas com microrganismo do rúmen ou enzimas extraídas destas últimas. 
O CNCPS apresenta para taxa de degradação da fração B3 da proteína de plantas tropicais valores variando de 0,09 a $10,50 \% / \mathrm{h}$, em média a taxa de degradação é de 2,38\%/h. Para plantas de Guiné (Panicum maximum), a taxa de degradação de B3 é de 6,60 a $10,50 \% / \mathrm{h}$.

O objetivo deste trabalho foi avaliar a cinética ruminal da MS e das frações FDN, PB e PIDN (nitrogênio aderido ao FDN) de amostras de pastejo simulado de capim Tanzânia (Panicum maximum Jacq.) coletadas em três épocas do ano (verão, outono e primavera) em pastagens irrigadas submetidas a três resíduos pós-pastejo (baixo, médio e alto).

\section{Material e Métodos}

O experimento foi conduzido na Fazenda Areão da Escola Superior de Agricultura "Luiz de Queiroz" da Universidade de São Paulo, em Piracicaba, São Paulo (22 42'30" lat. S; 470 38'00" long. W; $546 \mathrm{~m}$ altitude). A forragem utilizada foi o capim-Tanzânia (Panicum maximum Jacq.) estabelecido em área irrigada por pivô central. A pastagem foi manejada pelo método de pastejo rotacionado com 33 dias de descanso e três dias de ocupação. Os tratamentos, com quatro repetições, foram constituídos de três níveis de resíduo pós-pastejo (baixo, médio e alto). Os valores de resíduo pós-pastejo correspondentes aos períodos de avaliação da cinética ruminal constam da Tabela 1. Cada parcela foi dividida em três piquetes de $1.330 \mathrm{~m}^{2}$, com o objetivo de facilitar o manejo, possibilitando o ciclo de pastejo proposto. As amostragens foram sempre realizadas no mesmo piquete de cada parcela.

O solo foi corrigido para garantir os seguintes níveis de fertilidade: saturação por bases, $80 \%$; fósforo, $30 \mathrm{mg} / \mathrm{dm}^{3}$; potássio, $5 \%$ da CTC. Imediatamente após cada pastejo os piquetes eram adubados com $80 \mathrm{~kg} / \mathrm{ha}$ de $\mathrm{N}$ e $80 \mathrm{~kg} / \mathrm{ha}$ de $\mathrm{K}_{2} \mathrm{O}$ em todos os ciclos ao longo de 1 ano.

A pastagem foi formada em abril de 1999, o primeiro pastejo foi em agosto de 1999, após esse, mais dois pastejos se sucederam, os quais foram chamados de pastejo de estabelecimento dos tratamentos.

Foram coletadas amostras simulando o pastejo em três épocas distintas do ano: verão, outono e primavera. As amostras coletadas nos meses de dezembro e janeiro, foram correspondentes à estação de verão, as amostras de abril corresponderam às amostras de outono e as de outubro às de primavera.

As amostras coletadas em dezembro/janeiro, foram incubadas em fevereiro, as colhidas em abril foram incubadas em maio e as de outubro foram incubadas em novembro/dezembro.

Para cada um dos três períodos de incubação foram usados três animais com fístula de rúmen. $\mathrm{O}$ delineamento experimental para degradação ruminal foi um quadrado latino $3 \times 3$ (três animais em três períodos) para cada uma das épocas do ano.

Tabela 1 - Resíduo pós-pastejo em kg de MS verde (kg MSV/ha) em quatro épocas do ano para três níveis de resíduo (baixo, médio e alto)

Table 1 - Post grazed stubble in kg green matter (kg GDM/ha) on four periods of the year for three post grazed stubbles intensities (low, medium and high)

\begin{tabular}{|c|c|c|c|c|}
\hline $\begin{array}{l}\text { Tratamento } \\
\text { Treatment }\end{array}$ & $\begin{array}{l}\text { Época } 1 \\
\text { Period } 1\end{array}$ & $\begin{array}{l}\text { Época } 2 \\
\text { Period } 2\end{array}$ & $\begin{array}{l}\text { Época } 3 \\
\text { Period } 3\end{array}$ & $\begin{array}{l}\text { Época } 4 \\
\text { Period } 4\end{array}$ \\
\hline & & & & \\
\hline $\begin{array}{l}\text { Baixo } \\
\text { Low }\end{array}$ & $1277^{\text {Aab }}$ & $1763^{\mathrm{Aa}}$ & $816^{\mathrm{Ab}}$ & $1210^{\mathrm{Aab}}$ \\
\hline $\begin{array}{l}\text { Médio } \\
\text { Medium }\end{array}$ & $2459^{\mathrm{Ba}}$ & $3346^{\mathrm{Bb}}$ & $2548^{\mathrm{Bab}}$ & $3306^{\mathrm{Bb}}$ \\
\hline $\begin{array}{l}\text { Alto } \\
\text { High }\end{array}$ & $3106^{\mathrm{Ca}}$ & $5335^{\mathrm{Cb}}$ & $3113^{\mathrm{Ca}}$ & $5471^{\mathrm{Cb}}$ \\
\hline
\end{tabular}

Época 1 - 29/10/1999 a 14/02/2000 (Period 1 - 10/29/1999 to 02/14/2000).

Época 2 - 15/02/2000 a 02/06/2000 (Period 2 - 02/15/2000 to 06/02/2000).

Época 3 - 03/06/2000 a 13/08/2000 (Period 3 - 06/03/2000 to 08/13/2000).

Época 4 - 18/09/2000 a 29/11/2000 (Period 4 - 09/18/2000 to 11/29/2000).

Médias seguidas da mesma letra minúscula na linha ou maiúscula na coluna não diferem significativamente $(P>0,05)($ Means followed by the same small/capital letter in the row/column do not differ [P>.05]). 
A degradabilidade foi estudada nos seguintes tempos de incubação: 0, 3, 6, 9, 12, 24, 30, 48, 60, 72 e 96 horas. Entre um período e outro do quadrado latino, os animais mudavam de tratamento, sendo cumprido um período de adaptação de 14 dias antes da incubação do material daquele tratamento.

A metodologia utilizada para a degradação ruminal foi a de Nocek (1988). A degradabilidade potencial (DP) e a degradabilidade efetiva (DE) da MS, FDN, $\mathrm{PB}$ e proteína insolúvel em detergente neutro (PIDN) foram calculadas utilizando-se o modelo matemático proposto por Mehrez \& Orskov (1977) e descrito por Grant \& Mertens (1992):

Degradação potencial:

$$
\mathrm{DP}=\mathrm{A}+\mathrm{B}\left(1-\mathrm{e}^{-\mathrm{c}(\mathrm{t}-\mathrm{T})}\right),
$$

em que: $\mathrm{DP}=$ degradabilidade potencial para o tempo $\mathrm{t}(\%) ; \mathrm{A}=$ fração solúvel (\% do original); $\mathrm{B}=$ fração potencialmente degradável ( $\%$ do original); $\mathrm{c}=$ taxa de degradação da fração $\mathrm{B}(\% / \mathrm{h}) ; \mathrm{t}=$ tempo de incubação (h); T = tempo de colonização (Lag time).

Degradação efetiva:

$$
\mathrm{DE}=\mathrm{A}+\left(\left(\mathrm{B} \times \mathrm{c}^{\left(-\mathrm{k}^{*} \mathrm{~T}\right)}\right) /(\mathrm{c}+\mathrm{k}),\right.
$$

em que: $\mathrm{DE}=$ Degradação efetiva $(\%) ; \mathrm{k}=$ taxa de passagem da fase sólida; $\mathrm{c}=$ taxa de degradação da fração $\mathrm{B}(\% / \mathrm{h}) ; \mathrm{T}=$ tempo de colonização (Lag time) $\mathrm{A}=$ fração solúvel (\% do original); $\mathrm{B}=$ fração potencialmente degradável ( $\%$ do original).
Para a degradação efetiva, foi feito o cálculo com duas taxas de passagem, 2 e $3,5 \% / \mathrm{h}$, representando uma categoria animal de menor e outra de maior consumo de MS, respectivamente.

A fração "A" foi obtida pela lavagem do material que não foi colocado no rúmen (tempo zero); a fração "B", por (100 - $(\mathrm{A}+\mathrm{C}))$; "C" é a fração indegradável, calculada como sendo o resíduo do último tempo de incubação, expresso em \%.

A taxa de degradação ("c"), foi calculada através da regressão do logaritmo natural $(\ln )$ do resíduo potencialmente degradável (B) entre o tempo de incubação logo após o lag time e o tempo de incubação de estabilização da degradação. O lag time é o tempo até o início da degradação da fração B.

O lag time foi calculado segundo o modelo proposto por McDonald (1981):

(ln RPD t0 - ln RPD t)/c,

em que: ln RPD t0 = logaritmo natural do resíduo potencialmente degradável no tempo 0 hora; ln RDP $\mathrm{t}=$ logaritmo natural do resíduo potencialmente degradável no último tempo utilizado de incubação; $\mathrm{c}=$ taxa de degradação da fração B $(\% / \mathrm{h})$.

As determinações dos componentes da parede celular seguiram as metodologias de Goering \& Van Soest (1970) e Van Soest et al. (1991). Para as frações nitrogenadas, adotaram-se as

Tabela 2 - Composição nutricional de amostras do pastejo simulado de capim-Tanzânia pastejado sob três níveis de resíduo pós-pastejo (baixo, médio e alto) e em três estações do ano (verão, outono e primavera)

Table 2 - Nutritional composition of Tanzânia grass simulated grazing samples collected during three periods of the year (Summer, Autumn and Spring), under three post grazed stubbles intensities (low, medium and high)

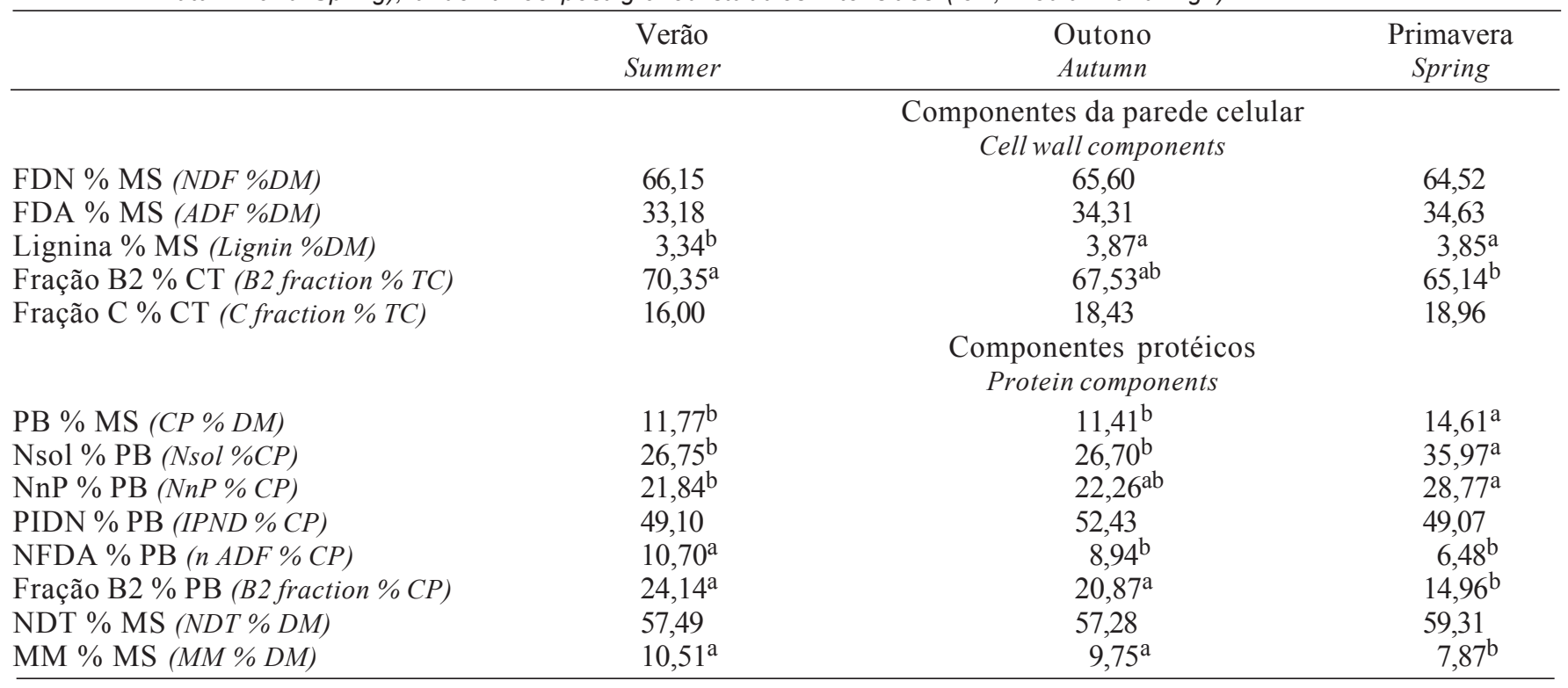

Médias seguidas da mesma letra na linha não diferem $(P>0,05)$ significativamente pelo teste Tukey.

Means followed by the same letter in the row do not differ $(P>.05)$ by Tukey test.

R. Bras. Zootec., v.32, n.6, p.1747-1762, 2003 (Supl. 1) 
metodologias de Krishnamoorthy et al. (1982) e Licitra et al. (1996).

As determinações da FDN, PB e PIDN no resíduo do material incubado foram realizadas através de espectroscopia de reflectância de infravermelho proximal (NIRS) (Berzaghi et al., 1997; Cozzolino et al., 2001). O equipamento utilizado foi um monocromato NIRS 5000 (NIRSystems, Silver Spring, MD, USA).

A composição nutricional da forragem para as diferentes estações do ano consta da Tabela 2. Como não houve diferenças entre os tratamentos, os valores expressam as médias dos três tratamentos em cada ciclo de amostragem de forragem.

A análise estatística foi feita considerando um delineamento em quadrado latino $3 \times 3$ com subamostras, constituído por três períodos, três animais, três tratamentos e quatro sub-amostras por tratamento. Este delineamento foi repetido em três épocas do ano.

Inicialmente, foi realizada uma análise por separado para cada época do ano. Diferenças significativas entre tratamentos foram testadas pelo teste Tukey, no nível de significância de 5\%. Posteriormente, procedeu-se à análise conjunta incluindo as três épocas do ano, seguindo a metodologia de Brien (2000) para o caso de quadrados latinos repetidos na mesma área em diferentes intervalos de tempo. Este delineamento permite testar o efeito da época do ano e a interação entre épocas e as duas fontes de variação do quadrado latino (período e animais) por separado, mas não permite testar a interação época do ano e tratamento.

As análises foram feitas usando o programa GENSTAT 5.0 (GENSTAT, 1999).

Posteriormente, foram realizadas correlações simples e múltiplas entre as degradações efetivas das frações e com alguns parâmetros nutricionais da planta. Os procedimentos usados foram o PROC CORR e PROC CANCORR do SAS (SAS, 1990)

\section{Resultados e Discussão}

Constam na Tabela 3 as frações da MS consideradas prontamente solúvel (A), potencialmente degradável (B) e indegradável (C). Não houve diferença significativa $(\mathrm{P}>0,05)$ para a fração $A$ entre os tratamentos para as três épocas do ano. A comparação das médias dos tratamentos em cada época do ano indicou menor fração solúvel para o período de verão em relação aos períodos de outono e primavera
$(16,70 ; 21,22$ e $19,34 \% \mathrm{MS}$, respectivamente, para verão, outono e primavera).

Não houve efeito de tratamento $(\mathrm{P}>0,05)$ para a fração potencialmente degradável B nas três épocas do ano. Para o período de verão, a fração B representou $63,32 \% \mathrm{MS}$, que foi maior quando comparado aos teores de outono $(54,52 \% \mathrm{MS})$ e de primavera $(55,70 \%$ MS). A soma das frações A e B foi maior para o resíduo pós-pastejo baixo no período de verão, enquanto para as demais épocas do ano não houve diferença entre os tratamentos $(\mathrm{P}>0,05)$.

No verão, a fração indegradável (C) foi menor para o resíduo pós-pastejo baixo (18,23\% MS), comparado aos teores dessa fração nos outros tratamentos; nas demais estações do ano não houve diferença entre os tratamentos $(\mathrm{P}>0,05)$ para essa fração. Em média, no verão a fração $\mathrm{C}$ foi menor $(19,98 \% \mathrm{MS})$, comparado às demais épocas do ano, o que mostra redução na qualidade da planta do verão para o outono e primavera. Isso demonstra que o subpastejo durante o verão predispõe à redução da qualidade da forragem. Em função do rápido crescimento da planta durante o verão no tratamento de maior resíduo póspastejo, é provável que tenha ocorrido elevado desenvolvimento de estruturas de sustentação. $\mathrm{O}$ mesmo comportamento não foi observado durante o outono e a primavera.

Seguindo a tendência de queda de qualidade do capim Tanzânia da estação de verão para o outono e primavera, verificam-se na Tabela 4 maiores taxas de degradação da MS para o verão $(5,62 \% / \mathrm{h})$, maior degradação potencial $(\mathrm{DP} \%=81,41 \%)$ e maior degradação efetiva, quando se considerou a taxa de passagem de $2 \% / \mathrm{h}(\mathrm{DE} 2 \%=64,56 \%)$.

Do verão para a primavera, a maior queda na degradação potencial da MS da forragem foi observada para o resíduo pós-pastejo baixo. Já para os tratamentos de resíduos pós-pastejo médio e alto, a redução na degradabilidade potencial foi de menos de 4 pontos percentuais e para o resíduo baixo, de 6,5 pontos percentuais. A redução da degradabilidade da forragem com resíduo pós-pastejo baixo pode ser evidenciada pela avaliação da DE 3,5\%; no verão ela era maior para este tratamento que para os resíduos póspastejos médio e alto, sendo que, na primavera, os tratamentos médio e alto passaram a ter maior DE 3,5\% que o baixo resíduo pós-pastejo.

As maiores degradabilidades, tanto para época do ano como para tratamentos, são explicadas pela maior proporção da fração potencialmente digestível 
Tabela 3 - Valores médios para as frações $A, B, A+B$ e C da matéria seca incubada no rúmen de amostras coletadas simulando o pastejo de capim-Tanzânia em três épocas do ano para três resíduos pós-pastejo

Table 3 - $A, B, A+B$ and $C$ fraction of dry matter of Tanzâniagrass incubated samples collected by simulating grazing during three periods of the year, under three post grazed stubbles intensities (low, medium and high)

\begin{tabular}{|c|c|c|c|c|}
\hline \multirow[t]{2}{*}{$\begin{array}{l}\text { Época do ano } \\
\text { Period of the year }\end{array}$} & \multicolumn{3}{|c|}{$\begin{array}{l}\text { Resíduo pós-pastejo } \\
\text { Post grazed stubble }\end{array}$} & \multirow[t]{2}{*}{$\begin{array}{l}\text { Média } \\
\text { Mean }\end{array}$} \\
\hline & $\begin{array}{l}\text { Baixo } \\
\text { Low }\end{array}$ & $\begin{array}{c}\text { Médio } \\
\text { Medium } \\
\end{array}$ & $\begin{array}{l}\text { Alto } \\
\text { High }\end{array}$ & \\
\hline & & $\begin{array}{l}\text { Fração A } \\
\text { A fraction }\end{array}$ & & \\
\hline $\begin{array}{l}\text { Verão } \\
\text { Summer }\end{array}$ & $16,76 \pm 1,82$ & $15,47 \pm 1,76$ & $17,86 \pm 0,90$ & $16,70^{\mathrm{B}}$ \\
\hline $\begin{array}{l}\text { Outono } \\
\text { Autumn }\end{array}$ & $21,91 \pm 0,55$ & $20,94 \pm 1,13$ & $20,80 \pm 0,84$ & $21,22^{\mathrm{A}}$ \\
\hline $\begin{array}{l}\text { Primavera } \\
\text { Spring }\end{array}$ & $17,29 \pm 2,13$ & $\begin{array}{c}19,52 \pm 1,97 \\
\text { Fração B } \\
\text { B fraction }\end{array}$ & $21,22 \pm 0,90$ & $19,34^{\mathrm{A}}$ \\
\hline $\begin{array}{l}\text { Verão } \\
\text { Summer }\end{array}$ & $65,00 \pm 2,02$ & $63,60 \pm 1,53$ & $61,36 \pm 1,13$ & $63,32^{\mathrm{A}}$ \\
\hline $\begin{array}{l}\text { Outono } \\
\text { Autumn }\end{array}$ & $54,65 \pm 1,04$ & $54,44 \pm 1,48$ & $54,48 \pm 0,92$ & $54,52^{\mathrm{B}}$ \\
\hline $\begin{array}{l}\text { Primavera } \\
\text { Spring }\end{array}$ & $58,70 \pm 2,43$ & $\begin{array}{c}55,40 \pm 2,06 \\
\text { Fração A + B } \\
A+B \text { fraction }\end{array}$ & $52,80 \pm 1,52$ & $55,70^{\mathrm{B}}$ \\
\hline $\begin{array}{l}\text { Verão } \\
\text { Summer }\end{array}$ & $81,77^{\mathrm{a}} \pm 0,56$ & $79,06^{b} \pm 0,58$ & $79,23^{b} \pm 0,86$ & $80,02^{\mathrm{A}}$ \\
\hline $\begin{array}{l}\text { Outono } \\
\text { Autumn }\end{array}$ & $76,56 \pm 1,28$ & $75,38 \pm 1,11$ & $75,28 \pm 1,11$ & $75,74^{\mathrm{B}}$ \\
\hline $\begin{array}{l}\text { Primavera } \\
\text { Spring }\end{array}$ & $76,03 \pm 1,01$ & $\begin{array}{c}74,96 \pm 0,71 \\
\text { Fração C } \\
\text { Cfraction }\end{array}$ & $74,06 \pm 1,69$ & $75,02^{\mathrm{B}}$ \\
\hline $\begin{array}{l}\text { Verão } \\
\text { Summer }\end{array}$ & $18,23^{\mathrm{b}} \pm 0,56$ & $20,94^{\mathrm{a}} \pm 0,58$ & $20,77^{\mathrm{a}} \pm 0,86$ & $19,98^{\mathrm{B}}$ \\
\hline $\begin{array}{l}\text { Outono } \\
\text { Autumn }\end{array}$ & $23,44 \pm 1,28$ & $24,62 \pm 1,11$ & $24,72 \pm 1,11$ & $24,26^{\mathrm{A}}$ \\
\hline $\begin{array}{l}\text { Primavera } \\
\text { Spring }\end{array}$ & $23,97 \pm 1,01$ & $25,04 \pm 0,71$ & $25,94 \pm 1,69$ & $24,98^{\mathrm{A}}$ \\
\hline
\end{tabular}

Médias seguidas da mesma letra minúscula na linha ou maiúscula na coluna não diferem $(P>0,05)$ significativamente pelo teste Tukey. Means followed by the same capital/small letter in the column/row do not differ ( $P>.05)$ by Tukey test.

$(\mathrm{A}+\mathrm{B})$ e pela menor proporção da fração indegradável (C). A maior degradação potencial ocorreu no tratamento de baixo resíduo pós-pastejo no verão, em que a proporção da fração $\mathrm{C}$ era a menor $(\mathrm{C}=18,23 \%)$ e a porção potencialmente degradável, a maior ( $\mathrm{A}+\mathrm{B}=81,41 \%)$.

No atual trabalho, a tendência de menor degradabilidade da MS na primavera em relação ao verão, pode ser explicada pelo florescimento. Em se tratando de áreas irrigadas, o comportamento dessas plantas foi diferente do observado em pastagens de sequeiro, sendo que o florescimento ocorreu em diferentes momentos ao longo do ano. Visualmente o maior florescimento se deu no mês de abril (outono)
(Santos, 2002), ocorrendo um segundo pico no mês de junho (inverno). Assim, na primavera havia acúmulo de perfilhos que floresceram em momentos diferentes, determinando menor degradabilidade da MS nessa época do ano.

A fração considerada solúvel da FDN não mostrou diferenças significativas $(\mathrm{P}>0,05)$ entre as épocas do ano, apesar do aumento de teor do verão para a primavera (Tabela 5). Essa tendência de aumento no teor da fração A da FDN ficou evidente no resíduo póspastejo baixo, onde para o verão foi de $5,42 \%$ MS e para a primavera foi de $14,00 \% \mathrm{MS}$. No verão, o maior teor da fração A foi para o tratamento alto, enquanto na primavera o maior teor foi para o tratamento baixo. 
Tabela 4 - Taxa de degradação (c), degradação efetiva com $2 \%$ de taxa de passagem (DE $2 \%$ ), degradação efetiva com $3,5 \%$ de taxa de passagem (DE 3,5\%) e degradação potencial (DP\%) no rúmen da matéria seca de amostras coletadas simulando o pastejo de capim-Tanzânia

Table 4 - Degradation rate (c), effective degradation considering $2 \%$ of passage rate (ED $2 \%$ ), effective degradation considering $3.5 \%$ passage rate $(3.5 \%$ ED) and potential degradation of dry matter on rumen for Tanzâniagrass simulated grazing samples

\begin{tabular}{|c|c|c|c|c|}
\hline \multirow[t]{2}{*}{$\begin{array}{l}\text { Época do ano } \\
\text { Period of the year }\end{array}$} & \multicolumn{3}{|c|}{$\begin{array}{l}\text { Resíduo pós-pastejo } \\
\text { Post grazed stubble }\end{array}$} & \multirow[t]{2}{*}{$\begin{array}{l}\text { Média } \\
\text { Mean }\end{array}$} \\
\hline & $\begin{array}{l}\text { Baixo } \\
\text { Low }\end{array}$ & $\begin{array}{l}\text { Médio } \\
\text { Medium }\end{array}$ & $\begin{array}{l}\text { Alto } \\
\text { High }\end{array}$ & \\
\hline \multicolumn{5}{|c|}{ Taxa de degradação (c) } \\
\hline $\begin{array}{l}\text { Verão } \\
\text { Summer }\end{array}$ & $5,62^{\mathrm{a}} \pm 0,20$ & $5,14^{\mathrm{a}} \pm 0,25$ & $4,52^{\mathrm{b}} \pm 0,24$ & 5,09 \\
\hline $\begin{array}{l}\text { Outono } \\
\text { Autumn }\end{array}$ & $4,89^{\mathrm{a}} \pm 0,20$ & $3,93^{\mathrm{b}} \pm 0,24$ & $4,35^{b} \pm 0,23$ & 4,39 \\
\hline $\begin{array}{l}\text { Primavera } \\
\text { Sprino }\end{array}$ & $4,22 \pm 0,12$ & $4,66 \pm 0,14$ & $4,46 \pm 0,11$ & 4,45 \\
\hline \multicolumn{5}{|c|}{$\begin{array}{l}\text { Degradação efetiva (DE 2\%) } \\
\text { Effective degradation (ED 2\%) }\end{array}$} \\
\hline $\begin{array}{l}\text { Verão } \\
\text { Summer }\end{array}$ & $64,56^{\mathrm{a}} \pm 0,77$ & $61,15^{\mathrm{b}} \pm 0,96$ & $60,07^{\mathrm{b}} \pm 0,76$ & $61,93^{\mathrm{A}}$ \\
\hline $\begin{array}{l}\text { Outono } \\
\text { Autumn }\end{array}$ & $60,81^{\mathrm{a}} \pm 0,92$ & $57,11^{\mathrm{b}} \pm 0,97$ & $57,90^{\mathrm{b}} \pm 1,27$ & $58,60^{\mathrm{B}}$ \\
\hline $\begin{array}{l}\text { Primavera } \\
\text { Spring }\end{array}$ & $57,07 \pm 0,77$ & $58,24 \pm 1,06$ & $59,57 \pm 0,92$ & $58,30^{\mathrm{B}}$ \\
\hline \multicolumn{5}{|c|}{$\begin{array}{l}\text { Degradação efetiva (DE 3,5\%) } \\
\text { Effective degradation (ED 3.5\%) }\end{array}$} \\
\hline $\begin{array}{l}\text { Verão } \\
\text { Summer }\end{array}$ & $56,66^{\mathrm{a}} \pm 0,95$ & $53,15^{\mathrm{b}} \pm 1,13$ & $52,12^{\mathrm{b}} \pm 0,85$ & 53,98 \\
\hline $\begin{array}{l}\text { Outono } \\
\text { Autumn }\end{array}$ & $53,82^{\mathrm{a}} \pm 0,88$ & $49,82^{\mathrm{b}} \pm 0,97$ & $50,79^{\mathrm{b}} \pm 1,28$ & 51,47 \\
\hline $\begin{array}{l}\text { Primavera } \\
\text { Spring }\end{array}$ & $49,34^{\mathrm{b}} \pm 0,92$ & $51,12^{\mathrm{ab}} \pm 1,12$ & $52,86^{\mathrm{a}} \pm 1,18$ & 51,11 \\
\hline \multicolumn{5}{|c|}{$\begin{array}{c}\text { Degradação potencial (DP\%) } \\
\text { Potential degradation }(P D \%)\end{array}$} \\
\hline $\begin{array}{l}\text { Verão } \\
\text { Summer }\end{array}$ & $81,41^{\mathrm{a}} \pm 0,57$ & $78,45^{\mathrm{b}} \pm 0,58$ & $78,07^{\mathrm{b}} \pm 0,80$ & $79,31^{\mathrm{A}}$ \\
\hline $\begin{array}{l}\text { Outono } \\
\text { Autumn }\end{array}$ & $76,37 \pm 1,10$ & $74,25 \pm 0,93$ & $74,23 \pm 1,17$ & $74,95^{\mathrm{B}}$ \\
\hline $\begin{array}{l}\text { Primavera } \\
\text { Spring }\end{array}$ & $74,96 \pm 0,93$ & $74,27 \pm 0,74$ & $74,81 \pm 0,81$ & $74,68^{\mathrm{B}}$ \\
\hline
\end{tabular}

Médias seguidas da mesma letra minúscula na linha ou maiúscula na coluna não diferem $(P>0,05)$ significativamente pelo teste Tukey. Means followed by the same capital/small letter in the column/row do not differ $(P>.05)$ by Tukey test.

A fração B e a soma de A e B foram maiores no período de verão, quando comparados aos períodos de outono e primavera, da mesma forma que a fração C foi menor para o verão em relação ao outono e primavera. No verão, o tratamento médio apresentou o menor teor da soma das frações A e B e o maior para a fração $\mathrm{C}$, enquanto o alto teve o maior teor para a soma $\mathrm{A}+\mathrm{B}$ e o menor para a fração $\mathrm{C}$. Independentemente do nível de resíduo pós-pastejo, o capim-Tanzânia no verão apresentou a maior proporção de FDN potencialmente degradável e, conse- qüentemente, menor proporção da fração indegradável.

Para a fração $B$ não houve diferença entre os tratamentos para nenhuma época do ano. A maior tendência de redução da fração B pôde ser verificada no tratamento de baixo resíduo, onde no verão o seu teor foi de $75,64 \% \mathrm{MS}$, enquanto na primavera, $61,91 \% \mathrm{MS}$

A fração C da FDN, obtida pelo resíduo da degradação de 96 horas de incubação (Tabela 5), indicou valores maiores que os obtidos pelo cálculo da 
Tabela 5 - Valores médios para as frações $A, B, A+B$ e $C$ da FDN incubada no rúmen de amostras coletadas simulando o pastejo de capim-Tanzânia

Table 5 - $A, B, A+B$ and $C$ fraction of NDF of Tanzâniagrass incubated samples collected by simulating grazing

\begin{tabular}{|c|c|c|c|c|}
\hline \multirow[t]{2}{*}{$\begin{array}{l}\text { Época do ano } \\
\text { Period of the year }\end{array}$} & \multicolumn{3}{|c|}{$\begin{array}{l}\text { Resíduo pós-pastejo } \\
\text { Post grazed stubble }\end{array}$} & \multirow[t]{2}{*}{$\begin{array}{l}\text { Média } \\
\text { Mean }\end{array}$} \\
\hline & $\begin{array}{l}\text { Baixo } \\
\text { Low }\end{array}$ & $\begin{array}{l}\text { Médio } \\
\text { Medium }\end{array}$ & $\begin{array}{l}\text { Alto } \\
\text { High }\end{array}$ & \\
\hline Verão & $5,42^{b} \pm 1,49$ & $\begin{array}{c}\text { Fração A } \\
\text { A fraction } \\
4,46^{\mathrm{b}} \pm 1,16\end{array}$ & $9,80^{\mathrm{a}} \pm 1,31$ & 6,56 \\
\hline $\begin{array}{l}\text { Summer } \\
\text { Outono } \\
\text { Autumn }\end{array}$ & $9,61^{\mathrm{a}} \pm 1,37$ & $8,43^{a} \pm 1,62$ & $4,10^{\mathrm{b}} \pm 0,97$ & 7,38 \\
\hline $\begin{array}{l}\text { Primavera } \\
\text { Spring }\end{array}$ & $14,00^{\mathrm{a}} \pm 1,39$ & $\begin{array}{c}8,81^{\mathrm{b}} \pm 0,84 \\
\text { Fração B } \\
\text { B fraction }\end{array}$ & $7,64^{b} \pm 1,61$ & 10,15 \\
\hline $\begin{array}{l}\text { Verão } \\
\text { Summer }\end{array}$ & $75,64 \pm 1,38$ & $74,44 \pm 1,03$ & $73,14 \pm 1,16$ & $74,41^{\mathrm{A}}$ \\
\hline $\begin{array}{l}\text { Outono } \\
\text { Autumn }\end{array}$ & $67,80 \pm 2,13$ & $66,90 \pm 2,02$ & $70,80 \pm 1,49$ & $68,50^{\mathrm{B}}$ \\
\hline $\begin{array}{l}\text { Primavera } \\
\text { Spring }\end{array}$ & $61,91 \pm 0,81$ & $\begin{array}{c}64,26 \pm 0,78 \\
\text { Fração A + B } \\
A+B \text { fraction }\end{array}$ & $65,20 \pm 2,25$ & $63,79^{\mathrm{B}}$ \\
\hline $\begin{array}{l}\text { Verão } \\
\text { Summer }\end{array}$ & $81,06^{\mathrm{b}} \pm 0,63$ & $78,90^{\mathrm{c}} \pm 0,48$ & $82,93^{a} \pm 0,25$ & $80,96^{\mathrm{A}}$ \\
\hline $\begin{array}{l}\text { Outono } \\
\text { Autumn }\end{array}$ & $77,55 \pm 1,07$ & $75,32 \pm 1,50$ & $75,08 \pm 1,29$ & $75,98^{\mathrm{B}}$ \\
\hline $\begin{array}{l}\text { Primavera } \\
\text { Spring }\end{array}$ & $75,85 \pm 1,23$ & $\begin{array}{c}\text { 74,21 } \pm 1,02 \\
\text { Fração C } \\
\text { Cfraction }\end{array}$ & $72,78 \pm 2,56$ & $74,28^{\mathrm{B}}$ \\
\hline $\begin{array}{l}\text { Verão } \\
\text { Summer }\end{array}$ & $19,07^{b} \pm 0,70$ & $22,43^{a} \pm 1,00$ & $16,72^{\mathrm{c}} \pm 0,41$ & $19,40^{\mathrm{B}}$ \\
\hline $\begin{array}{l}\text { Outono } \\
\text { Autumn }\end{array}$ & $22,52 \pm 1,06$ & $24,68 \pm 1,50$ & $25,65 \pm 1,18$ & $24,29^{\mathrm{A}}$ \\
\hline $\begin{array}{l}\text { Primavera } \\
\text { Spring }\end{array}$ & $23,80 \pm 1,25$ & $25,80 \pm 0,98$ & $27,39 \pm 2,54$ & $25,66^{\mathrm{A}}$ \\
\hline
\end{tabular}

Médias seguidas da mesma letra minúscula na linha ou maiúscula na coluna não diferem $(P>0,05)$ significativamente pelo teste Tukey. Means followed by the same capital/small letter in the column/row do not differ $(P>.05)$ by Tukey test.

Lignina/FDN multiplicado por 2,4 (Tabela 2). Esse fator $(2,4)$, como já verificado por Traxler et al. (1998), parece ser maior para plantas tropicais. Nesse caso, considerando os valores da Tabela 5, encontram-se como fatores multiplicadores da lignina os valores entre 2,91 e 3,35, sendo maior para a primavera, o que indica o mesmo teor de lignina alterando a disponibilidade da FDN de forma diferenciada.

A taxa de degradação da FDN com variação entre 3,74 e $5,99 \% /$ h está dentro da faixa sugerida pelo CNCPS, entre 3 e $8,10 \% /$ h para plantas tropicais, entretanto o CNCPS apresenta para Panicum maximum um valor mais alto, $7 \% / \mathrm{h}$. As taxas de degradação da FDN obtidas por Ribeiro et al.
(2001) para plantas de Tifton, entre 4 e $4,60 \% / \mathrm{h}$, são semelhantes às taxas encontradas no presente trabalho, ao contrário das obtidas por Vieira et al. (2000b), onde as taxas de degradação da FDN em pastagens nativas para os períodos de secas e águas foram, respectivamente de 9 e $6,2 \% / \mathrm{h}$.

Como pode ser visto na Tabela 6, a taxa de degradação da FDN apresentou tendência de redução do verão para a primavera. A redução na taxa de degradação provocou a queda da DE 2\%, DE 3,5\% e da $\mathrm{DP} \%$ do verão para o outono e primavera. A redução das degradações da FDN entre as épocas do ano foi mais evidente para o resíduo pós-pastejo alto, onde a DE $2 \%$ foi de 61,92 para $46,70 \%$, a DE $3,5 \%$ 
foi de 52,76 para $39,45 \%$ e a $\mathrm{DP} \%$ foi de 82,15 para $63,77 \%$. As plantas manejadas em resíduos mais altos também apresentavam maiores alturas no momento do pastejo (Penati, 2002). Essa maior altura deve ser suportada por uma parede celular mais rígida, sendo esse o provável motivo pelo qual as plantas do tratamento de maior resíduo apresentaram menor qualidade da parede celular.

Vieira et al. (2000b) em pastagens nativas encontraram redução na degradação efetiva do período de verão para o inverno. Os valores obtidos por Vieira et al. (2000b) foram de 73,50 e 68,50\%, respectivamente para verão e inverno. Esses valores são maiores que os encontrados no atual trabalho, mesmo considerando as maiores degradações efetivas calculadas com taxa de passagem de $2 \% / \mathrm{h}$ obtidas no verão $(60,87 \%)$.

Na primavera, nenhum dos parâmetros de cinética ruminal avaliados para parede celular mostrou diferenças entre os tratamentos $(\mathrm{P}>0,05)$, enquanto, no verão, houve menores taxas de degradação (DE 2\%, DE 3,5\% e DP\%) para o resíduo pós-pastejo médio. No outono, devido a maior queda da degradabilidade da FDN do tratamento de alto resíduo, o tratamento de baixo resíduo passou a apresentar as maiores degradações (Tabela 6).

Tabela 6 - Valores médios para taxa de degradação (c), degradação efetiva com 2\% de taxa de passagem (DE 2\%), degradação efetiva com 3,5\% de taxa de passagem (DE 3,5\%) e degradação potencial (DP) para a FDN incubada no rúmen de amostras coletadas simulando o pastejo de capim-Tanzânia

Table 6 - Degradation rate (c), effective degradation considering $2 \%$ of passage rate (ED $2 \%$ ), effective degradation considering $3.5 \%$ passage rate $(3.5 \%$ ED) and potential degradation of NDF on rumen for Tanzâniagrass simulated grazing samples

\begin{tabular}{|c|c|c|c|c|}
\hline \multirow[t]{2}{*}{$\begin{array}{l}\text { Época do ano } \\
\text { Period of the year }\end{array}$} & \multicolumn{3}{|c|}{$\begin{array}{l}\text { Resíduo pós-pastejo } \\
\text { Post grazed stubble }\end{array}$} & \multirow[t]{2}{*}{$\begin{array}{l}\text { Média } \\
\text { Mean }\end{array}$} \\
\hline & $\begin{array}{l}\text { Baixo } \\
\text { Low }\end{array}$ & $\begin{array}{l}\text { Médio } \\
\text { Medium }\end{array}$ & $\begin{array}{l}\text { Alto } \\
\text { High }\end{array}$ & \\
\hline \multicolumn{5}{|c|}{$\begin{array}{c}\text { Taxa de degradação (c) } \\
\text { Degradation rate (c) }\end{array}$} \\
\hline Verão & $5,99^{a} \pm 0,20$ & $5,36^{\mathrm{b}} \pm 0,21$ & $5,11^{\mathrm{b}} \pm 0,18$ & 5,49 \\
\hline Summer & & & & \\
\hline $\begin{array}{l}\text { Outono } \\
\text { Autumn }\end{array}$ & $5,19 \pm 0,36$ & $4,59 \pm 0,33$ & $4,68 \pm 0,44$ & 4,82 \\
\hline $\begin{array}{l}\text { Primavera } \\
\text { Spring }\end{array}$ & $3,98 \pm 0,19$ & $3,74 \pm 0,50$ & $4,03 \pm 0,19$ & 3,91 \\
\hline \multicolumn{5}{|c|}{$\begin{array}{l}\text { Degradação efetiva (DE 2\%) } \\
\text { Effective degradation (ED 2\%) }\end{array}$} \\
\hline $\begin{array}{l}\text { Verão } \\
\text { Summer }\end{array}$ & $61,87^{\mathrm{a}} \pm 0,96$ & $58,81^{b} \pm 0,83$ & $61,92^{\mathrm{a}} \pm 0,76$ & $60,87^{\mathrm{A}}$ \\
\hline $\begin{array}{l}\text { Outono } \\
\text { Autumn }\end{array}$ & $60,10^{\mathrm{a}} \pm 0,80$ & $55,48^{\mathrm{b}} \pm 1,17$ & $52,42^{b} \pm 2,16$ & $56,00^{\mathrm{B}}$ \\
\hline $\begin{array}{l}\text { Primavera } \\
\text { Spring }\end{array}$ & $54,90 \pm 1,42$ & $52,70 \pm 1,90$ & $46,70 \pm 4,85$ & $51,40^{\mathrm{B}}$ \\
\hline \multicolumn{5}{|c|}{$\begin{array}{l}\text { Degradação efetiva (DE 3,5\%) } \\
\text { Effective degradation (ED 3,5\%) }\end{array}$} \\
\hline $\begin{array}{l}\text { Verão } \\
\text { Summer }\end{array}$ & $52,87^{\mathrm{a}} \pm 1,09$ & $49,68^{b} \pm 0,96$ & $52,76^{\mathrm{a}} \pm 0,92$ & $51,77^{\mathrm{A}}$ \\
\hline $\begin{array}{l}\text { Outono } \\
\text { Autumn }\end{array}$ & $51,91^{\mathrm{a}} \pm 0,77$ & $46,90^{b} \pm 1,10$ & $43,31^{b} \pm 2,31$ & $47,38^{\mathrm{B}}$ \\
\hline $\begin{array}{l}\text { Primavera } \\
\text { Spring }\end{array}$ & $46.86 \pm 1,35$ & $44.51 \pm 1,82$ & $39.45 \pm 3,98$ & $43.61^{\mathrm{B}}$ \\
\hline \multicolumn{5}{|c|}{$\begin{array}{c}\text { Degradação potencial (DP\%) } \\
\text { Potential degradation }(P D \%)\end{array}$} \\
\hline $\begin{array}{l}\text { Verão } \\
\text { Summer }\end{array}$ & $80,76^{\mathrm{b}} \pm 0,66$ & $78,45^{\mathrm{c}} \pm 0,51$ & $82,15^{\mathrm{a}} \pm 0,31$ & $80,45^{\mathrm{A}}$ \\
\hline $\begin{array}{l}\text { Outono } \\
\text { Autumn }\end{array}$ & $77,48^{\mathrm{a}} \pm 1,02$ & $74,87^{\mathrm{b}} \pm 1,19$ & $73,28^{b} \pm 1,64$ & $75,21^{\mathrm{B}}$ \\
\hline $\begin{array}{l}\text { Primavera } \\
\text { Spring }\end{array}$ & $73,55 \pm 1,70$ & $71,34 \pm 1,91$ & $63,77 \pm 7,02$ & $69,55^{\mathrm{B}}$ \\
\hline
\end{tabular}

Médias seguidas da mesma letra minúscula na linha ou maiúscula na coluna não diferem $(P>0,05)$ significativamente pelo teste Tukey. Means followed by the same capital/small letter in the column/row do not differ ( $P>$.05) by Tukey test. 
Dechamps (1999) observou para Brachiaria brizantha correlação de 0,95 entre a degradação da MS e a degradação da FDN. Entretanto, o tratamento de alto resíduo, do verão para a primavera, apresentou queda maior na degradabilidade da FDN que para MS, enquanto a redução na degradabilidade da MS, para os tratamentos baixo e médio resíduos, foi mais próxima da queda de degradabilidade da FDN. A menor relação entre as degradabilidades da FDN e da MS na primavera deve estar associada à qualidade da parede celular, especificamente ao teor de lignina (Tabela 2) e à forma de ligação com a hemicelulose, evidentemente mais resistente em virtude do acúmulo de perfilhos florescidos.
A fração A da proteína bruta foi menor para a época da primavera $(28,60 \% \mathrm{~PB})$, enquanto que, a menor porção indisponível (fração C) foi observada para o período de verão $(9,01 \%$ PB). A maior fração indegradável foi encontrado na primavera $(16,57 \%$ PB). A fração B não mostrou diferenças entre as épocas do ano, no entanto a soma de A e B foi maior para o verão comparada às outras épocas do ano (Tabela 7).

Somente para o verão houve diferença $(\mathrm{P}<0,05)$ na qualidade da proteína entre os tratamentos. $\mathrm{O}$ tratamento médio, no verão, apresentou menor proporção de A + B e maior proporção da fração C. A fração A foi maior para o tratamento baixo $(41,33 \%$ PB)

Tabela 7 - Valores médios para as frações $A, B, A+B$ e $C$ da proteína bruta de amostras incubadas no rúmen coletadas simulando o pastejo de capim-Tanzânia

Table 7 - A, B, A+B and C fraction crude protein of Tanzâniagrass incubated samples collected by simulating grazing

\begin{tabular}{|c|c|c|c|c|}
\hline \multirow[t]{2}{*}{$\begin{array}{l}\text { Época do ano } \\
\text { Period of the year }\end{array}$} & \multicolumn{3}{|c|}{$\begin{array}{l}\text { Resíduo pós-pastejo } \\
\text { Post grazed stubble }\end{array}$} & \multirow[t]{2}{*}{$\begin{array}{l}\text { Média } \\
\text { Mean }\end{array}$} \\
\hline & $\begin{array}{l}\text { Baixo } \\
\text { Low }\end{array}$ & $\begin{array}{l}\text { Médio } \\
\text { Medium }\end{array}$ & $\begin{array}{l}\text { Alto } \\
\text { High }\end{array}$ & \\
\hline & & $\begin{array}{l}\text { Fração A } \\
\text { A fraction }\end{array}$ & & \\
\hline Verão & $41,33^{\mathrm{a}} \pm 1,31$ & $37,89^{\mathrm{ab}} \pm 2,41$ & $33,86^{\mathrm{b}} \pm 1,96$ & $37,69^{\mathrm{A}}$ \\
\hline $\begin{array}{l}\text { Summer } \\
\text { Outono }\end{array}$ & $36,20 \pm 1,69$ & $38,80 \pm 1,66$ & $34,00 \pm 2,85$ & $36,30^{\mathrm{A}}$ \\
\hline $\begin{array}{l}\text { Autumn } \\
\text { Primavera }\end{array}$ & $28,60 \pm 3,43$ & $32,70 \pm 2,97$ & $24,50 \pm 2,47$ & $28,60^{\mathrm{B}}$ \\
\hline Spring & & $\begin{array}{l}\text { Fração B } \\
\text { B fraction }\end{array}$ & & \\
\hline $\begin{array}{l}\text { Verão } \\
\text { Summer }\end{array}$ & $53,60 \pm 3,73$ & $52,00 \pm 2,23$ & $59,40 \pm 2,20$ & 55,00 \\
\hline $\begin{array}{l}\text { Outono } \\
\text { Autumn }\end{array}$ & $48,90 \pm 1,61$ & $46,50 \pm 1,93$ & $57,70 \pm 4,72$ & 51,10 \\
\hline $\begin{array}{l}\text { Primavera } \\
\text { Spring }\end{array}$ & $55,40 \pm 3,20$ & $50,80 \pm 2,41$ & $57,60 \pm 2,54$ & 54,60 \\
\hline & & $\begin{array}{l}\text { Fração A + B } \\
A+B \text { fraction }\end{array}$ & & \\
\hline Verão & $91,47^{a} \pm 0,29$ & $89,93^{\mathrm{b}} \pm 0,24$ & $91,57^{\mathrm{a}} \pm 0,25$ & $90,99^{\mathrm{A}}$ \\
\hline $\begin{array}{l}\text { Summer } \\
\text { Outono }\end{array}$ & $86,32 \pm 0,58$ & $85,76 \pm 0,71$ & $85,77 \pm 0,61$ & $85,95^{\mathrm{B}}$ \\
\hline $\begin{array}{l}\text { Autumn } \\
\text { Primavera } \\
\text { Spring }\end{array}$ & $83,94 \pm 0,91$ & $\begin{array}{c}84,38 \pm 1,01 \\
\text { Fração C } \\
\text { Cfraction }\end{array}$ & $82,05 \pm 1,55$ & $83,46^{\mathrm{B}}$ \\
\hline $\begin{array}{l}\text { Verão } \\
\text { Summer }\end{array}$ & $8,53^{b} \pm 0,29$ & $10,07^{\mathrm{a}} \pm 0,24$ & $8,43^{b} \pm 0,25$ & $9,01^{\mathrm{C}}$ \\
\hline $\begin{array}{l}\text { Outono } \\
\text { Autumn }\end{array}$ & $13,66 \pm 0,58$ & $14,22 \pm 0,71$ & $14,23 \pm 0,61$ & $14,04^{\mathrm{B}}$ \\
\hline $\begin{array}{l}\text { Primavera } \\
\text { Spring }\end{array}$ & $16,10 \pm 1,02$ & $15,66 \pm 1,01$ & $17,95 \pm 1,55$ & $16,57^{\mathrm{A}}$ \\
\hline
\end{tabular}

Médias seguidas da mesma letra minúscula na linha ou maiúscula na coluna não diferem $(P>0,05)$ significativamente pelo teste Tukey. Means followed by the same capital/small letter in the column/row do not differ $(P>.05)$ by Tukey test. 
comparado ao alto resíduo $(33,86 \%$ PB) (Tabela 7$)$.

A distribuição das frações da proteína evidencia a alta proporção da fração solúvel nas plantas tropicais, as quais atingem mais de $50 \%$ da proteína degradável no rúmen e está de acordo com Balsalobre (1996) que, para capim-elefante (Pennisetum purpureum), encontrou $39,11 \%$ da proteína na forma solúvel. Estão também de acordo com Malafaia et al. (1997), que, em quatro espécies de plantas forrageiras tropicais, encontraram como proteína prontamente solúvel cerca de $33 \%$ da proteína total. Entretanto, Lima et al. (1999) concluíram, em suas avaliações de frações nitrogenadas de outras três plantas forrageiras, que a proteína de rápida degradação ruminal esteve em níveis baixos, chegando à valores de $12 \%$ da proteína total (entre 12 e $38 \%$ da proteína como sendo solúvel).

A taxa de degradação da proteína não se alterou entre as épocas do ano, no entanto, para o resíduo pós-pastejo baixo houve tendência para ser menor na primavera que no verão. No verão e outono a taxa de degradação foi maior para o tratamento baixo comparado aos demais (Tabela 8 ).

A literatura apresenta uma variação muito ampla

Tabela 8 - Taxa de degradação (c), degradação efetiva com $2 \%$ de taxa de passagem (DE 2\%), degradação efetiva com $3,5 \%$ de taxa de passagem (DE 3,5\%) e degradação potencial (DP) para a proteína bruta incubada no rúmen de amostras coletadas simulando o pastejo de capim-Tanzânia

Table 8 - Degradation rate (c), effective degradation considering 2\% of passage rate (ED 2\%), effective degradation considering $3.5 \%$ passage rate $(3.5 \% \mathrm{ED})$ and potential degradation of crude protein on rumen for Tanzaniagrass simulated grazing samples

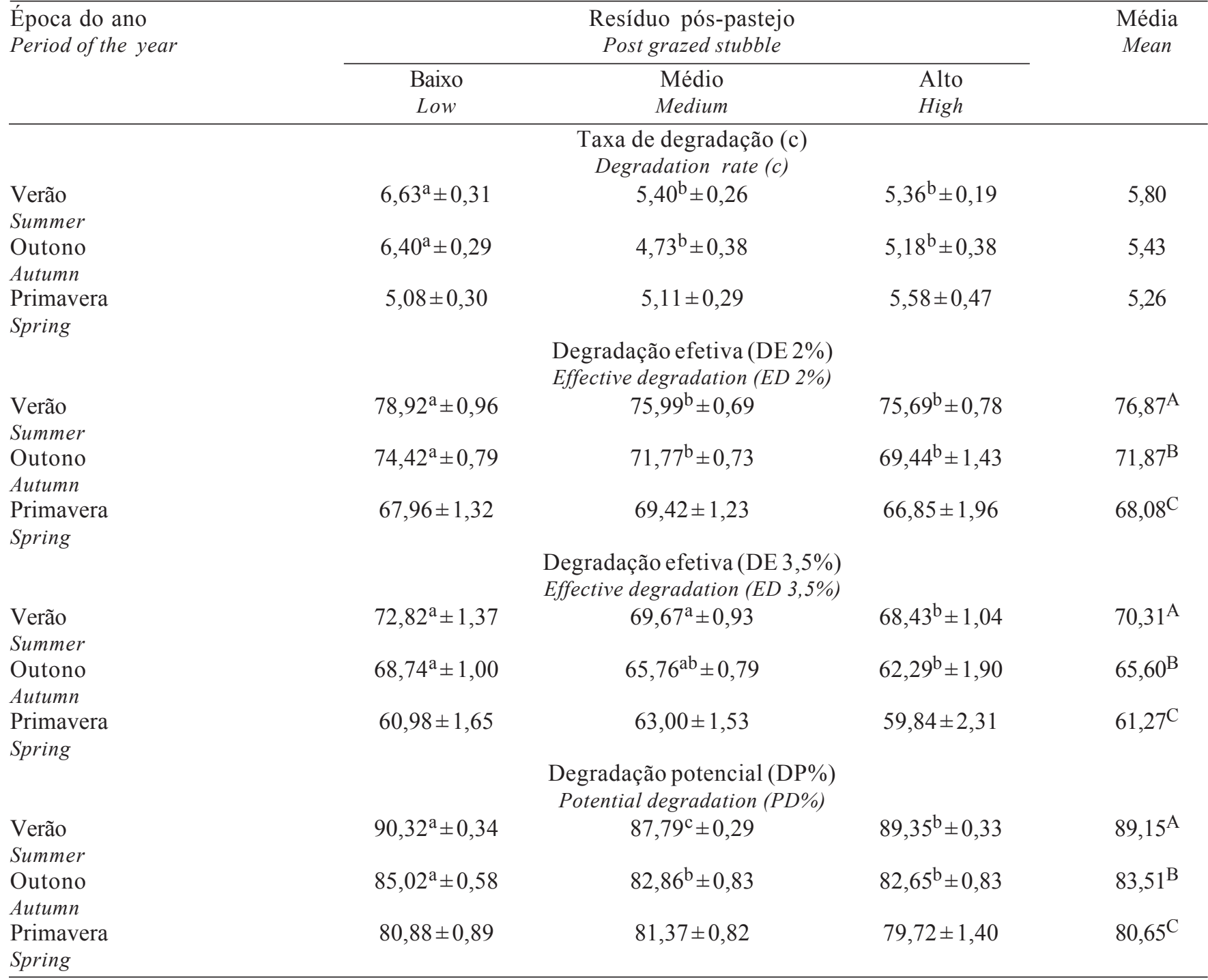

Médias seguidas da mesma letra minúscula na linha ou maiúscula na coluna não diferem $(P>0,05)$ significativamente pelo teste Tukey. Means followed by the same capital/small letter in the column/row do not differ $(P>.05)$ by Tukey test. 
para taxa de degradação da fração potencialmente degradável da proteína. O CNCPS, por exemplo, apresenta dados entre 0,09 e $10,50 \% / h$, enquanto Malafaia et al. (1997) obtiveram taxa de degradação dessa fração entre 0,06 e $0,95 \% / \mathrm{h}$ e Ribeiro et al. (2001), entre 0,77 e $1,20 \% / h$. Os valores de taxa de degradação da proteína obtidos por Vieira et al. (2000b), entre 3,2 e 8\%/h são próximos dos obtidos no atual trabalho, entre 4,73 e $6,63 \% / \mathrm{h}$.

As plantas de capim-Tanzânia manejadas em resíduo mais baixo apresentaram maior proporção de folhas que os tratamentos com intensidades de pastejo intermediária e baixa. Além disso, as folhas do tratamento de menor resíduo eram em maior porcentagem de folhas novas (Aguiar et al., 2001). Isso pode explicar o motivo pelo qual houve tendência para que a taxa de degradação da proteína para o tratamento de resíduo mais baixo fosse maior que os outros tratamentos (Tabela 8).

As degradações efetiva e potencial foram menores na primavera e maiores no verão. A DE $2 \%$ variou de $76,87 \%$ (no verão) a $68,08 \%$ (na primavera) e a DE $3,5 \%$ foi de 70,31 para $61,27 \%$ entre o verão e a primavera, respectivamente. Da mesma forma, a DP variou entre 89,15 e $80,65 \%$, respectivamente para verão e primavera.

Nos períodos de verão e outono o tratamento baixo apresentou as maiores DE $2 \%$ e DP. Nessas mesmas épocas do ano, o tratamento alto teve a menor DE 3,5\%. Para a primavera não houve diferenças $(P>0,05)$ entre os tratamentos para taxa de degradação e degradações efetivas e potencial. A degradação potencial, que nesse trabalho variou de 79,72 a $90,32 \%$, foi maior que a encontrada por Vieira et al. (2000b), que em pastagens nativas encontraram DP variando de 59,50 a 79,60, respectivamente para inverno e verão. Os valores de Vieira et al. (2000b) foram inferiores, mesmo tendo esses trabalhado com enzimas oriundas de Streptomyces griseus, a qual resulta em maiores taxas de degradações e consequentemente maior digestão.

A relação da proteína degradável no rúmen com a matéria seca degradável no rúmen é um parâmetro usado na tentativa da melhor sincronização ruminal entre carboidratos e proteína. Considerando as degradações da proteína e da matéria seca para as taxas de passagem de 2 e 3,5\%, inicialmente houve excesso de proteína no rúmen em relação a matéria seca degradável (Balsalobre, 2002).

A relação proteína degradável no rúmen e matéria seca degradável no rúmen deve ser levada em consideração em uma eventual suplementação concentrada para animais pastejando esse tipo de forragem. Pode-se inferir que, nesse caso, não seria aconselhável trabalhar com uréia, pois já existe proteína de rápida degradação em excesso. A relação da fração A da proteína com a fração A da MS (entre 19,51 e 26,58\%) indica que há uma desproporção entre essas, uma vez que apresentam taxas de degradação semelhantes.

Desse modo, a suplementação concentrada em pastagens de capim Tanzânia adubado e irrigado, deve ter dois objetivos: em um primeiro momento adição de carboidratos solúveis de rápida degradação ruminal; segundo, adição de proteína de boa qualidade e de degradação moderada.

A fração A do PIDN foi de pequena proporção e não apresentou diferenças $(\mathrm{P}>0,05)$ entre os tratamentos e épocas do ano (Tabela 9). As frações B e a soma de $\mathrm{A}$ e $\mathrm{B}$ foram maiores para o verão, conseqüentemente, a fração $\mathrm{C}$ foi menor para esse período em relação às épocas de outono e primavera. No verão as frações $\mathrm{B}, \mathrm{A}+\mathrm{B}$ e C foram, respectivamente, de 75,19; 75,32 e 24,68\% PIDN.

A fração $\mathrm{C}$ da PIDN indica a porção de proteína que está aderida à parede celular que não pode ser degradada. Por determinação líquida, esse valor representa a proteína associada à FDA (N-FDA), que apresentou variação de 6,48 a 10,70\% (Tabela 2). No entanto, considerando a concentração de PIDN na $\mathrm{PB}$ e os teores da fração $\mathrm{C}$ indicados na Tabela 9, obtêm-se teores entre 12,11 e $17,08 \%$ PB para a fração indegradável da proteína, ou seja, valores maiores que os obtidos em laboratório. Isso sugere que há alguma limitação na metodologia de determinação dessa fração em laboratório.

Na Tabela 10, observam-se, para o PIDN, maiores taxas de degradação, maior DE 2\%, maior DE $3,5 \%$ e maior DP para o verão quando comparado ao outono e primavera. O PIDN é a porção da planta que, em relação à cinética ruminal, mais apresentou alteração ao longo das estações do ano. Sua taxa de degradação, que era de $6,49 \% / \mathrm{h}$ para o verão, reduziu para $3,62 \% / \mathrm{h}$ na primavera. A DE $2 \%$ apresentou redução de 10,50 pontos percentuais, enquanto a $\mathrm{DE} 3,5 \%$, 11,38 pontos percentuais do verão para a primavera.

Não houve diferenças entre os tratamentos para taxas de degradação, a não ser para a época de outono, quando foi menor para o tratamento alto. As degradações efetivas e potencial tiveram tendência de serem maiores em todas épocas do ano para o 
tratamento baixo em comparação aos demais. A DE $2 \%$ e DE 3,5\% apresentou grande variação do maior para o menor valor, 21,16 e 21,31 pontos percentuais, respectivamente.

A análise de correlação simples de alguns parâmetros com as taxas de degradação indica que, para MS e FDN, não existe, na análise nutricional dessas forragens, uma fração que se destaque na explicação da degradabilidade ruminal. No caso da MS, o teor de FDN explica apenas $9 \%$ de sua degradação. A lignina que deveria ser o melhor parâmetro para se explicar a degradação da MS apresenta coeficiente de degradação muito baixo $(16,64)$.
Os teores de FDN, FDA, hemicelulose e lignina praticamente não apresentaram correlação com as degradações de FDN (tabela 11).

A degradação da proteína bruta, no entanto, é em grande parte explicada por suas frações (Nsol, NnP, PIDN) e pelo seu teor, principalmente, pela concentração de PIDN, que representou em torno de $50 \%$ da PB e explica $25 \%$ da degradação da proteína. Quanto maior o teor de PIDN menor foi a degradação da PB, da mesma forma que quanto maior o nível de proteína na planta, pior foi sua degradação. Por outro lado, quanto maiores os teores de $\mathrm{NnP}$ e Nsol, maior foi a degradabilidade ruminal da proteína. $\mathrm{O}$ nFDA não teve boa correlação com a degradação da proteína,

Tabela 9 - Valores médios para as frações A, B, A+B e C da PIDN incubada no rúmen de amostras coletadas simulando o pastejo de capim-Tanzânia

Table 9 - $A, B, A+B$ and $C$ fraction of IPND of Tanzâniagrass incubated samples collected by simulating grazing

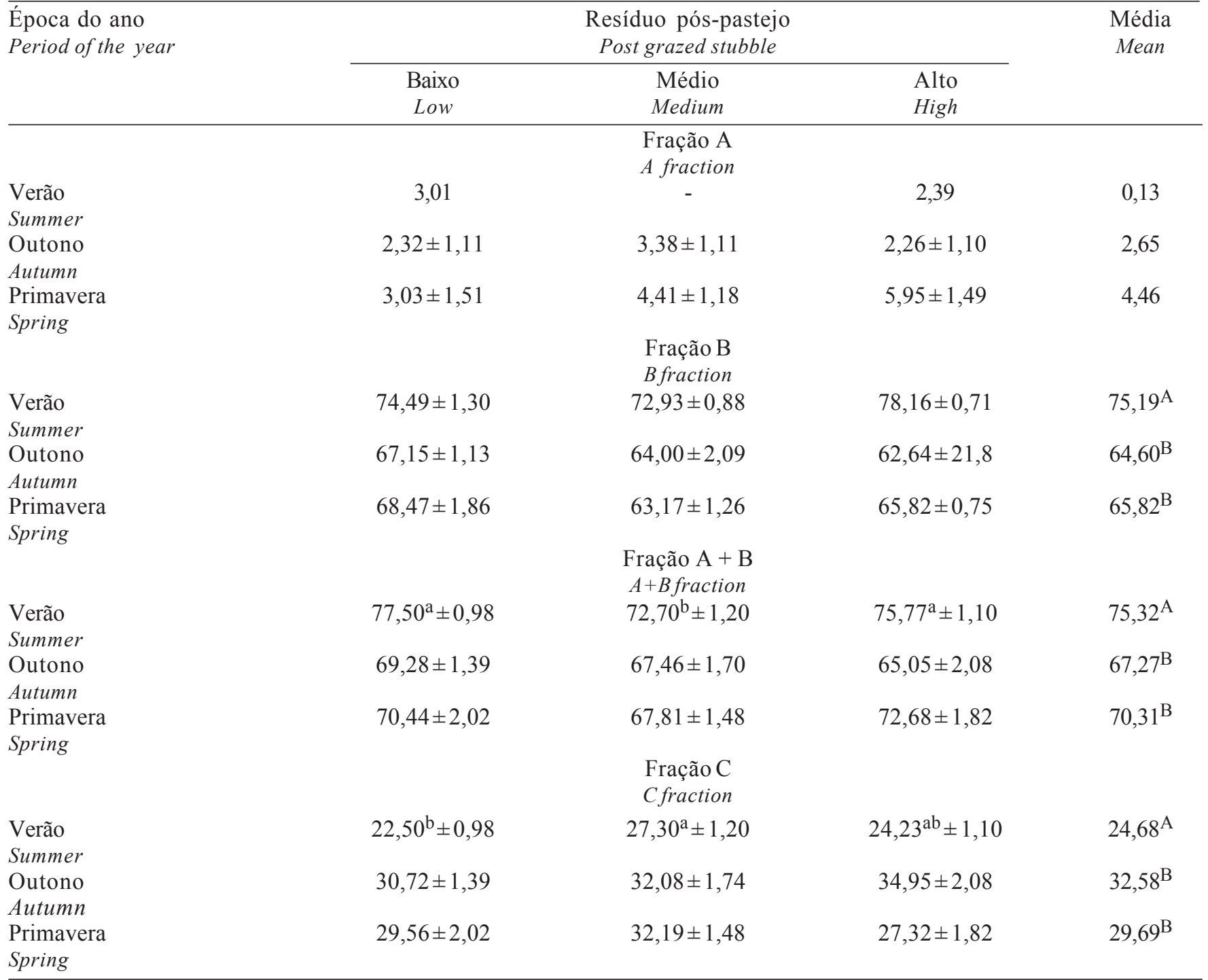

Médias seguidas da mesma letra minúscula na linha ou maiúscula na coluna não diferem $(P>0,05)$ significativamente pelo teste Tukey. Means followed by the same capital/small letter in the column/row do not differ $(P>.05)$ by Tukey test. 
Tabela 10 - Taxa de degradação (c), degradação efetiva com $2 \%$ de taxa de passagem (DE 2\%), degradação efetiva com $3,5 \%$ de taxa de passagem (DE 3,5\%) e degradação potencial (DP) para a PIDN incubada no rúmen de coletadas amostras simulando o pastejo de capim-Tanzânia

Table 10 - Degradation rate (c), effective degradation considering $2 \%$ of passage rate (ED 2\%), effective degradation considering $3.5 \%$ passage rate $(3.5 \%$ ED) and potential degradation of IPND on rumen for Tanzâniagrass simulated grazing samples

\begin{tabular}{|c|c|c|c|c|}
\hline \multirow[t]{2}{*}{$\begin{array}{l}\text { Época do ano } \\
\text { Period of the year }\end{array}$} & \multicolumn{3}{|c|}{$\begin{array}{l}\text { Resíduo pós-pastejo } \\
\text { Post grazed stubble }\end{array}$} & \multirow[t]{2}{*}{$\begin{array}{l}\text { Média } \\
\text { Mean }\end{array}$} \\
\hline & $\begin{array}{l}\text { Baixo } \\
\text { Low }\end{array}$ & $\begin{array}{l}\text { Médio } \\
\text { Medium }\end{array}$ & $\begin{array}{l}\text { Alto } \\
\text { High }\end{array}$ & \\
\hline \multicolumn{5}{|c|}{$\begin{array}{c}\text { Taxa de degradação (c) } \\
\text { Degradation rate (c) }\end{array}$} \\
\hline Verão & $6,62 \pm 0,44$ & $6,38 \pm 0,65$ & $6,46 \pm 0,47$ & $6,49^{\mathrm{A}}$ \\
\hline $\begin{array}{l}\text { Summer } \\
\text { Outono } \\
\text { Autumn }\end{array}$ & $4,81^{\mathrm{a}} \pm 0,66$ & $3,92^{\mathrm{ab}} \pm 0,47$ & $2,99^{b} \pm 0,31$ & $3,91^{\mathrm{B}}$ \\
\hline $\begin{array}{l}\text { Primavera } \\
\text { Spring }\end{array}$ & $3,61 \pm 0,31$ & $3,71 \pm 0,37$ & $3,53 \pm 0,25$ & $3,62^{\mathrm{B}}$ \\
\hline \multicolumn{5}{|c|}{$\begin{array}{l}\text { Degradação efetiva (DE 2\%) } \\
\text { Effective degradation (ED 2\%) }\end{array}$} \\
\hline Verão & $60,86^{\mathrm{a}} \pm 1,02$ & $55,93^{b} \pm 1,77$ & $57,20^{\mathrm{b}} \pm 1,28$ & $58,00^{\mathrm{A}}$ \\
\hline $\begin{array}{l}\text { Summer } \\
\text { Outono }\end{array}$ & $48,90^{\mathrm{a}} \pm 1,43$ & $46,60^{a} \pm 1,65$ & $39,70^{\mathrm{b}} \pm 1,14$ & $45,10^{\mathrm{B}}$ \\
\hline $\begin{array}{l}\text { Autumn } \\
\text { Primavera } \\
\text { Spring }\end{array}$ & $48,30 \pm 1,68$ & $50,60 \pm 1,50$ & $43,50 \pm 1,34$ & $47,50^{\mathrm{B}}$ \\
\hline \multicolumn{5}{|c|}{$\begin{array}{l}\text { Degradação efetiva (DE 3,5\%) } \\
\text { Effective degradation (ED 3.5\%) }\end{array}$} \\
\hline $\begin{array}{l}\text { Verão } \\
\text { Summer }\end{array}$ & $52,41^{\mathrm{a}} \pm 1,17$ & $47,51^{b} \pm 2,02$ & $47,92^{\mathrm{b}} \pm 1,45$ & $49,28^{\mathrm{A}}$ \\
\hline $\begin{array}{l}\text { Outono } \\
\text { Autumn }\end{array}$ & $40,60^{\mathrm{a}} \pm 1,62$ & $38,40^{\mathrm{a}} \pm 1,60$ & $31,10^{\mathrm{b}} \pm 1,14$ & $36,70^{\mathrm{B}}$ \\
\hline $\begin{array}{l}\text { Primavera } \\
\text { Spring }\end{array}$ & $39,20^{\mathrm{a}} \pm 1,76$ & $42,30^{\mathrm{a}} \pm 1,47$ & $35,10^{\mathrm{b}} \pm 1,27$ & $38,90^{\mathrm{B}}$ \\
\hline \multicolumn{5}{|c|}{$\begin{array}{c}\text { Degradação potencial (DP\%) } \\
\text { Potential degradation (PD\%) }\end{array}$} \\
\hline $\begin{array}{l}\text { Verão } \\
\text { Summer }\end{array}$ & $77,85^{\mathrm{a}} \pm 0,74$ & $73,11^{b} \pm 1,09$ & $76,78^{\mathrm{a}} \pm 0,93$ & $75,91^{\mathrm{A}}$ \\
\hline $\begin{array}{l}\text { Outono } \\
\text { Autumn }\end{array}$ & $67,68^{a} \pm 1,26$ & $65,30^{a b} \pm 1,72$ & $60,94^{b} \pm 1,68$ & $64,64^{\mathrm{B}}$ \\
\hline $\begin{array}{l}\text { Primavera } \\
\text { Spring }\end{array}$ & $69,80^{\mathrm{a}} \pm 1,84$ & $69,50^{a} \pm 1,52$ & $64,10^{b} \pm 1,70$ & $67,80^{\mathrm{B}}$ \\
\hline
\end{tabular}

Médias seguidas da mesma letra minúscula na linha ou maiúscula na coluna não diferem $(P>0,05)$ significativamente pelo teste Tukey. Means followed by the same capital/small letter in the column/row do not differ $(P>.05)$ by Tukey test.

talvez por seu baixo teor nas plantas (menor que $10 \%$ da PB). Essa baixa correlação do nFDA com a qualidade da proteína coloca em dúvida a análise dessa fração nesse tipo de forrageira.

A lignina apresentou correlação moderada, tanto para a degradabilidade da PB como do PIDN. Para a PB a correlação foi negativa, o coeficiente de correlação foi de 32,71. Entretanto, para o PIDN, a correlação, além de ter sido baixa $(32,47)$, foi positiva, demonstrando a variabilidade da análise de lignina e a importância de se conhecer com maior detalhe essa fração.

A correlação canônica (correlação múltipla) entre a degradação da PB e os teores de lignina,
PB, PIDN, NnP, nFDA e Nsol, apresentou coeficiente de $73,91 \%$. Isso significa que mais de $50 \%$ da degradação da PB é explicada por esses parâmetros. No caso da MS, a correlação múltipla de sua degradação com o teor de FDN, FDA, hemicelulose e lignina apresentou boa correlação $(51,60 \%)$. No entanto, a correlação positiva de teor da FDA com degradação da MS fica difícil de ser explicada.

A correlação múltipla das degradações do PIDN e da FDN foi relativamente baixa, 43,34; 21,34 e 25,49 , respectivamente, devendo existir outros parâmetros que melhor possam explicar essas degradações. 


\section{Conclusões}

O período de verão (dezembro e janeiro) apresentou a melhor qualidade da forragem quando comparada com as forragens amostradas em abril (outono) e outubro (primavera).

Houve tendência para o tratamento de menor resíduo pós-pastejo apresentar melhor qualidade no verão, no entanto do verão para a primavera foi o tratamento que apresentou maior redução de degradabilidade.

Para o tratamento alto, a redução na degradabilidade da FDN foi em maior proporção que para a MS, quando comparada aos outros tratamentos (baixo e médio).

Não há um parâmetro de qualidade nutricional que justifique adequadamente a cinética ruminal, tanto para MS, FDN, PB e PIDN. A degradação da proteína foi bem explicada pelos teores de $\mathrm{PB}$ e de suas frações. Quanto maior o teor de PB e de PIDN, pior foi a degradabilidade da PB.

\section{Literatura Citada}

AGUIAR, S.V.H.; BALSALOBRE, M.A.A.; LABONIA, V.D. de et al. Proporção de partes morfológicas do capim Tanzânia (Panicum maximum Jacq.) em três intensidades de pastejo ao longo do ano. In: REUNIÃO ANUAL DA SOCIEDADE BRASILEIRA DE ZOOTECNIA, 38., Piracicaba, 2001. Anais... Piracicaba: Sociedade Brasileira de Zootecnia, 2001. p.342-343.

BALSALOBRE, M.A.A. Valor alimentar do capim-Tanzânia irrigado. Piracicaba: Escola Superior de Agricultura "Luiz de Queiroz”, 2002.113p. Tese (Doutorado) - Escola Superior de Agricultura “Luiz de Queiroz", 2002.

BALSALOBRE, M.A.A. Desempenho de vacas em lactação sob pastejo rotacionado de capim-elefante (Pennisetum purpureum Schum.). Piracicaba: Escola Superior de Agricultura "Luiz de Queiroz", 1996. 139p. Dissertação (Mestrado) - Escola Superior de Agricultura "Luiz de Queiroz", 1996.

BERZAGHI, P.; COZZI, G.; ANDRIGHETTO, I. The use of near infrared analysis for in situ studies. Journal of Dairy Science, v.80, p.3263-3270, 1997.

BRIEN, C. Sets of latin squares. In: http:// linus.levels.unisa.edu.au/ matcjb/research/dammnotes.html. ed. University of South Australia, School of Mathematics. The Design \& Mixed-model Analysis of Experiments. Cap. 8, 2000.

CABAllero, R.; AlZUETA, C.; ORTIZ, L.T. et al. Carbohydrate and protein fractions of fresh and dried Common Vetch at three maturity stages. Agronomy Journal, v.93, p.1006-1013, 2001.

COZZOLINO, D.; ACOSTA, Y.; GARCIA, J. Application of near infrared reflectance spectroscopy (NIRS) to forage evaluation in Uruguay. In: PROCEEDINGS OF THE
INTERNATIONAL GRASSLAND CONGRESS, 19., 2001, São Pedro. Anais... Piracicaba: Fundação de Estudos Agrários "Luiz de Queiroz”, 2001. p.370.

DECHAMPS, F.C. Implicações do período de crescimento na composição química e digestão dos tecidos de cultivares de capim elefante. Revista Brasileira de Zootecnia, v.28, n.6, p.1178-1189, 1999.

FOX, D.G.; SNIFFEN, C.J.; O'CONNOR et al. A net carbohydrate and protein system for evaluating cattle diets: III. Cattle requirements and diet adequacy. Journal of Animal Science, v.70, p.3578-3596, 1992.

FRITZ, J.O.; MOORE, K.J.; JASTER, E.H. Digestion kinetics and cell wall composition of brown Midrib Sorghum x Sudan grass morphological components. Crop Science, v.30, p.213-219, 1990.

GENSTAT 5 Release 4.1 Reference Manual, Genstat 5 Committee ed. Numerical Algoritms Group, 1999.

GOERING, H.K.; Van SOEST, P.J. Forage fiber analyses (apparatus, reagents, procedures, and some applications). Washington: ARS-USDA, 1970. 19p. (Agricultural Handbook, 379).

GRANT, R.J.; MERTENS, D.R. Influence of buffer $\mathrm{pH}$ and raw corn starch addition on in vitro fiber digestion kinetics. Journal of Dairy Science, v.75, p.2762-2768, 1992.

KRISHNAMOORTHY, U.C.; MUSCATO, T.V.; SNIFFEN, C.J. et al. Nitrogen fractions in selected feedstuffs. Journal of Dairy Science, v.65, p.217, 1982.

LICITRA, G.; HERNANDEZ, T.M.; Van SOEST, P.J. Standardization of procedures for nitrogen fractionation of ruminant feeds. Animal Feed Science Technology, v.57, p.347-358, 1996.

LIMA, G.F.C.; SOLLENBERGER, L.E.; MOORE, J.E. et al. Concentração e fracionamento do nitrogênio em gramíneas forrageiras tropicais e subtropicais (compact disc). In: REUNIÃO ANUAL DA SOCIEDADE BRASILEIRA DE ZOOTECNIA, 36., Porto Alegre, 1999. Anais... Porto Alegre: Sociedade Brasileira de Zootecnia, 1999.

MALAFAIA, P.A.M.; VALADARES FILHO, S.C.; VIEIRA, R.A.M. et al. Determinação da cinética ruminal das frações protéicas de alguns alimentos para ruminantes. Revista Brasileira de Zootecnia, v.26, n.6, p.1243-1251, 1997.

McDONALD, I. A revised model for the estimation of protein degradability in the rumen. Journal of Agricultural Science, v.96, n.1, p.251-252, 1981.

MEHREZ, A.Z.; ORSKOV, E.R. A study of the artificial fiber bag technique for determining the digestibility of feeds in the rumen. Journal of Agricultural Science, v.88, p.645-650, 1977.

MESSMAN, M.A.; WEISS, W.P.; ERICKSON, D.O. Effects of nitogen fertilization and maturity of bromegrass on in situ ruminal digestion kinetics of fiber. Journal of Animal Science, v.69, p.1151-1161, 1991.

NATIONAL RESEARCH COUNCIL - NRC. Nutrient Requirements of domestics animals. Nutrient requirements of beef cattle. Washington, D.C.: National Academy Science, 1996.

NOCEK, J.F. Evaluation of specific variables affecting in situ estimates of ruminal dry matter and protein digestion. Journal of Animal Science, v.60, p.1347-1358, 1988.

PENATI, M.A. Estudo do desempenho animal e produção do capim Tanzânia (Panicum maximum Jacq.) em um sistema

R. Bras. Zootec., v.32, n.6, p.1747-1762, 2003 (Supl. 1) 
rotacionado de pastejo sob irrigação em três níveis de resíduo pós-pastejo. Piracicaba: Escola Superior de Agricultura "Luiz de Queiroz", 2002. 117p. Tese (Doutorado). Escola Superior de Agricultura "Luiz de Queiroz”, Universidade de São Paulo.

RIBEIRO, G.K.; PEREIRA, O.G.; VALADARES FILHO, S.C. et al. Caracterização das frações que constituem as proteínas e os carboidratos, e respectivas taxas de digestão, do feno de capim-Tifton 85 de diferentes idades de rebrota. Revista Brasileira de Zootecnia, v.30, n.2, p.589-595, 2001.

RUSSEL, J.B.; O'CONNOR, J.D.; FOX, D.G. et al. A net carbohydrate and protein system for evaluating cattle diets: I. Ruminal fermentation. Journal of Animal Science, v.70, p.3551-3561, 1992.

SANTOS, P.M. Controle do desenvolvimento das hastes no capim-Tanzânia: um desafio. Piracicaba: Escola Superior de Agricultura "Luiz de Queiroz", 2002. 98p. Tese (Doutorado) - Escola Superior de Agricultura "Luiz de Queiroz", 2002.

STATISTICAL ANALYSIS SYSTEM - SAS. SAS User's guide: statistics. Cary: 1990. 956p.

SNIFFEN, C.J.; O'CONNOR, J.D.; Van SOEST, P.J. et al. A net carbohydrate and protein system for evaluating cattle diets: II. Carbohydrate and protein availability. Journal of Animal Science, v.70, p.3562-3577, 1992.

TRAXLER, M.J.; FOX, D.G.;Van SOEST, P.J. et al. Predicting forage indigestible NDF from lignina concentration. Journal of Animal Science, v.76, p.1469-1480, 1998.
Van SOEST, P.J.; ROBERTSON, J.B.; LEWIS, B.A. Methods for dietary fiber, neutral detergent fiber and nostarch polysaccharides in relation to animal nutrition. Journal of Dairy Science, v.74, p.3583 - 3597, 1991.

VIEIRA, R.A.M.; PEREIRA, J.C.; MALAFAIA, P.A. M. et al. Application of non-linear models in the description of in situ degradation profiles of the elephantgrass (Pennisetum purpureum Schum., Mineiro variety). Animal Feed Science and Technology, v.66, p.197-210, 1997.

VIEIRA, R.A.M.; PEREIRA, J.C.; MALAFAIA, P.A.M. Fracionamento e cinética de degradação in vitro dos compostos nitrogenados da extrusa de bovinos a pasto. Revista Brasileira de Zootecnia, v.29, n.3, p.880-888, 2000a.

VIEIRA, R.A.M.; PEREIRA, J.C.; MALAFAIA, P.A.M. Fracionamento dos carboidratos e cinética de degradação in vitro da fibra em detergente neutro da extrusa de bovinos a pasto. Revista Brasileira de Zootecnia, v.29, n.3, p.889-897, 2000b.

Recebido em: 30/01/02

Aceito em: 02/06/03 